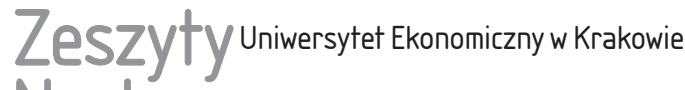 Naukowe
}

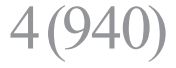

ISSN 1898-6447

Zesz. Nauk. UEK, 2015; 4(940): 5-17 DOI: 10.15678/ZNUEK.2015.0940.0401

Grzegorz Kończak

Katedra Statystyki

Uniwersytet Ekonomiczny w Katowicach

\section{O pewnej modyfikacji testu adaptacyjnego dla równości wartości oczekiwanych*}

\section{Streszczenie}

W opracowaniu przedstawiono propozycję modyfikacji testu adaptacyjnego dla porównania wartości oczekiwanych w dwóch populacjach. W zaproponowanym rozwiązaniu nie dokonuje się wyboru postaci statystyki testowej, lecz na podstawie danych pochodzących z wylosowanej próbki modyfikowane są wagi występujące w statystyce testowej. Własności rozważanego testu i testów klasycznych zostały porównane z wykorzystaniem symulacji komputerowych. Test może być wykorzystany w procedurach kontroli jakości. Nie wymaga on spełnienia ostrych założeń dotyczących postaci rozkładu zmiennej diagnostycznej i z tego powodu może być wykorzystywany do wykrywania rozregulowania procesu w przypadkach, gdy nie jest znana postać rozkładu zmiennej.

Słowa kluczowe: testy adaptacyjne, testy permutacyjne, porównanie populacji, Monte Carlo.

\section{Wprowadzenie}

Testy adaptacyjne należą do stosunkowo rzadko wykorzystywanych w praktyce badań ekonomicznych narzędzi statystycznych. Testy te zostały zaproponowane dla poprawienia skuteczności wnioskowania statystycznego w przypadkach,

* Projekt został sfinansowany ze środków Narodowego Centrum Nauki przyznanych na podstawie decyzji numer DEC-2011/03/B/HS4/05630. 
gdy nie są spełnione założenia stosowania klasycznych testów parametrycznych. $\mathrm{W}$ takich sytuacjach możliwe jest skorzystanie z testów nieparametrycznych, jednak charakteryzują się one mniejszą mocą niż ich odpowiedniki parametryczne. Testy adaptacyjne miały zapewnić moc porównywalną z testami parametrycznymi przy jednoczesnym osłabieniu założeń. Istotą testów adaptacyjnych jest modyfikacja procedury obliczeniowej w zależności od wylosowanej próby. Przykładem testu adaptacyjnego jest test $t$ dla porównania wartości oczekiwanych, w którym w zależności od porównania wariancji w badanych populacjach wykorzystuje się jedną z dwóch postaci statystyki testowej.

W opracowaniu przedstawiono propozycję testu adaptacyjnego dla porównania wartości oczekiwanych w dwóch populacjach. W zaproponowanym rozwiązaniu nie dokonuje się wyboru postaci statystyki testowej, lecz na podstawie danych pochodzących z wylosowanej próbki modyfikowane są wagi występujące w statystyce testowej. Własności rozważanego testu i testów klasycznych zostały porównane z wykorzystaniem symulacji komputerowych. Proponowany test może być wykorzystany w procedurach monitorowania jakości procesów. Test nie wymaga spełnienia ostrych założeń dotyczących postaci rozkładu zmiennej diagnostycznej i z tego powodu pozwala wykryć rozregulowania procesu w przypadku różnych postaci rozkładu. Wszystkie symulacje i obliczenia wykonano z wykorzystaniem programów R oraz Mathematica.

\section{Porównania populacji}

Jednym z kluczowych zadań związanych z badaniami statystycznymi są porównania populacji. Porównania mogą dotyczyć parametrów populacji (wartości oczekiwane, wariancje, wskaźniki struktury) lub np. postaci funkcyjnej rozkładów (porównanie dystrybuant lub funkcji gęstości). Badania mogą prowadzić do porównań dwóch populacji lub $k$ populacji, gdzie $k>2$. Przykładami testów parametrycznych, które do takich zadań są stosowane mogą być testy: $t$ dla wartości oczekiwanych, test $F$ równości wariancji, ANOVA, porównanie frakcji dwóch populacji.

Testy mogą być stosowane przy odpowiednich założeniach. Jeżeli nie są spełnione założenia dotyczące postaci rozkładu, to zwykle nie można odwołać się do testów parametrycznych. Dobrą alternatywą w takim przypadku są testy nieparametryczne. Testy takie charakteryzują się jednak zazwyczaj mniejszą mocą, co prowadzi do znacznie większych trudności w potwierdzeniu występujących różnic w populacjach. Przykładami takich testów są testy wykorzystujące rangi lub empiryczne dystrybuanty [Sheskin 2003, Domański i Pruska 2000]: $U$ Manna-Whitney’a, Kruskala-Wallisa, Kołmogorowa-Smirnova. 
W wielu przypadkach pomocne mogą być testy adaptacyjne, których zastosowanie często pozwala na osłabienie założeń dotyczących postaci rozkładów (jak w testach nieparametrycznych), a jednocześnie zapewniają dużą moc (jak w testach parametrycznych).

\section{Testy adaptacyjne}

Testy wykorzystujące dane próbkowe do modyfikacji statystyki lub procedury testowej określane są testami adaptacyjnymi [O’Gorman 2012]. Do najbardziej znanych testów adaptacyjnych należy zaliczyć test $t$ dla równości wartości oczekiwanych. Weryfikowana hipoteza i hipoteza alternatywna mogą być zapisane następująco:

$$
\begin{aligned}
& H_{0}: m_{1}=m_{2}, \\
& H_{1}: m_{1} \neq m_{2},
\end{aligned}
$$

W różnych problemach hipoteza alternatywna może być formułowana jako hipoteza kierunkowa. W zależności od wyniku porównania wariancji badanych populacji wykorzystywana jest jedna $\mathrm{z}$ dwóch następujących statystyk:

lub

$$
t=\frac{\bar{X}_{1}-\bar{X}_{2}}{\sqrt{\frac{n_{1} S_{1}^{2}+n_{2} S_{2}^{2}}{n_{1}+n_{2}-2}\left(\frac{1}{n_{1}}+\frac{1}{n_{2}}\right)}}
$$

$$
t=\frac{\bar{X}_{1}-\bar{X}_{2}}{\sqrt{\frac{S_{1}^{2}}{n_{1}}+\frac{S_{2}^{2}}{n_{2}}}},
$$

gdzie: $\bar{X}_{1}, \bar{X}_{2}, S_{1}^{2}, S_{2}^{2}, n_{1}, n_{2}$ to odpowiednio średnie, wariancje oraz liczebności pobranych prób.

Statystyka (1) stosowana jest dla populacji o jednakowych wariancjach, natomiast statystyka (2) dla populacji o różnych wariancjach. Przy założeniu hipotezy $H_{0}$ i spełnieniu stosownego warunku dotyczącego równości wariancji statystyka (1) ma rozkład $t$-Studenta o $k=n_{1}+n_{2}-2$ stopniach swobody, a statystyka (2) rozkład $t$-Studenta o $k=\frac{\left(\frac{\hat{S}_{1}^{2}}{n_{1}}+\frac{\hat{S}_{2}^{2}}{n_{2}}\right)^{2}}{\frac{\left(\frac{\hat{S}_{1}^{2}}{n_{1}}\right)^{2}}{n_{1}-1}+\frac{\left(\frac{\hat{S}_{2}^{2}}{n_{2}}\right)^{2}}{n_{2}-1}}$ stopniach swobody. Dla stosowania testu $t$ próby powinny być pobrane z populacji o rozkładach normalnych. Dopuszczalne są niewielkie odstępstwa od normalności rozkładu. 
R.V. Hogg, D.M. Fisher i R.H. Randles [1975] zaproponowali test adaptacyjny (w dalszej części dla testu przyjęto oznaczenie $H F R$ ) dla porównania wartości oczekiwanych, dla którego nie jest wymagane spełnienie założenia normalności rozkładów. Po wylosowaniu prób z dwóch populacji o dowolnych ciągłych rozkładach wyznaczane są odporne oceny asymetrii $Q_{3}$ i kurtozy $Q_{4}$ dla połączonych prób.

$$
\begin{gathered}
Q_{3}=\frac{\bar{U}_{0,05}-\bar{M}_{0,50}}{\bar{M}_{0,50}-\bar{L}_{0,05}}, \\
\bar{U}_{4}=\frac{\bar{U}_{0,05}-\bar{L}_{0,05}}{\bar{U}_{0,50}-\bar{L}_{0,50}},
\end{gathered}
$$

gdzie: $\bar{U}_{a}, \bar{L}_{a}, \bar{M}_{a}$ to odpowiednio średnie z $100 a \%$ największych, najmniejszych i środkowych wartości połączonych prób.

W zależności od wartości statystyk $Q_{3}$ i $Q_{4}$ do weryfikacji hipotezy o równości wartości oczekiwanych wybierana jest statystyka testu mediany, testu Wilcoxona, testu dla prawoskośnego rozkładu lub dla rozkładu o „lekkich ogonach”. Schemat wyboru statystyki przedstawiono na rys. 1 .

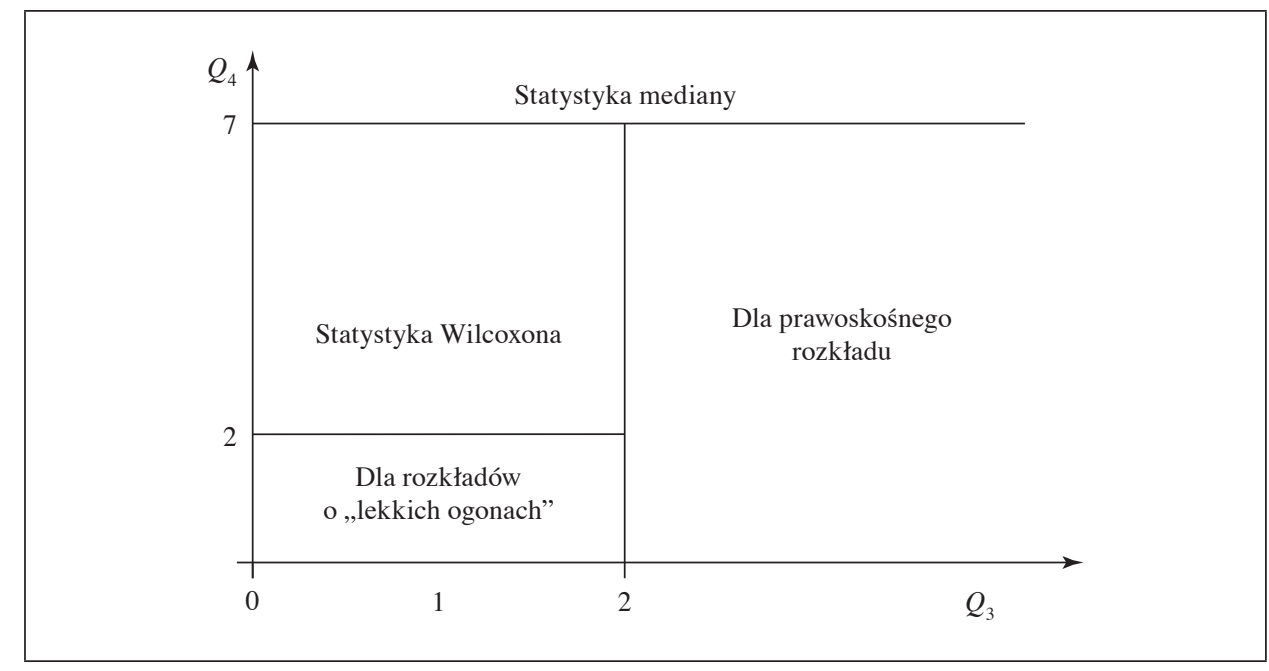

Rys. 1. Schemat wyboru statystyki dla testu $H F R$

Źródło: opracowanie własne na podstawie: [O’Gorman 2012].

Zmodyfikowaną postać testu HFR przedstawiają L. Hao i D. Houser [2012] (w dalszej części oznaczanego jako test $H H$ ). L. Hao i D. Houser na podstawie przeprowadzonych symulacji wykazali, że granice obszarów powinny być nieco inaczej wyznaczone (por. rys. $2, Q_{3}^{*}$ wynosi 2,1 a $Q_{4}^{*}$ dla prób o liczebności 11-15 


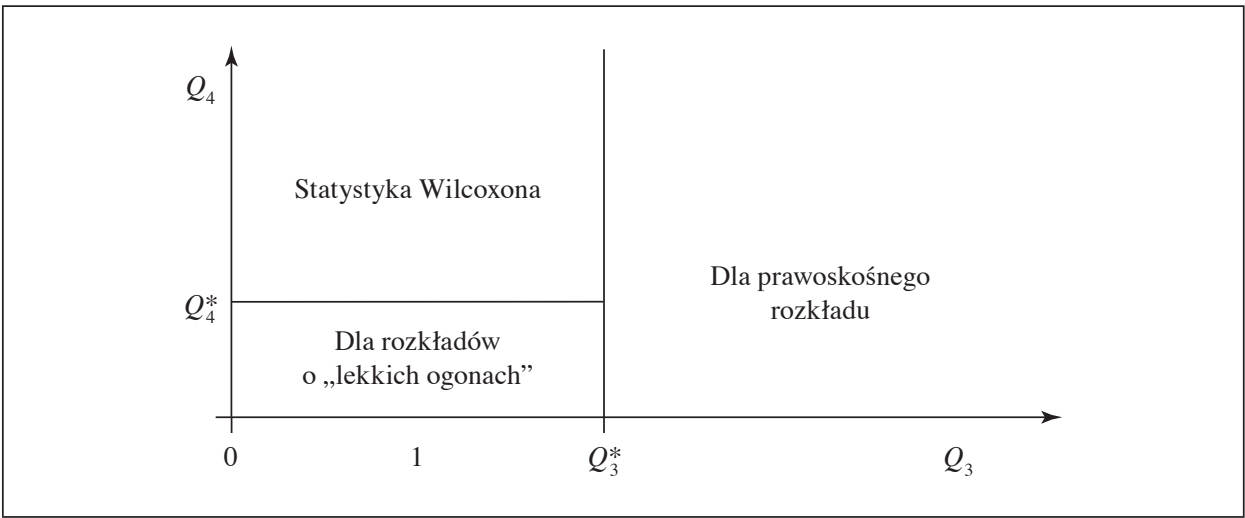

$Q_{3}^{*}$ wynosi 2,1, a $Q_{4}^{*}$ dla prób o liczebności 11-15 2,0, a dla większych od 15 2,1.

Rys. 2. Schemat wyboru statystyki dla modyfikacji $H H$

Źródło: opracowanie własne na podstawie: [Hao i Houser 2012].

2,0, a dla większych od 15 2,1). Zaproponowali również odrzucenie obszaru, dla którego przeprowadzano test mediany ze względu na słabą moc testu.

\section{Propozycja adaptacyjnej statystyki testowej}

Zarówno test $H F R$, jak i modyfikacja zaproponowana przez L. Hao i D. Houser charakteryzują się pewną nieciągłością. W pobliżu granic wyróżnionych obszarów zaznaczonych na rys. 1 i 2 nawet bardzo niewielka zmiana danych próbkowych może prowadzić do zmiany procedury testowej, a w konsekwencji do podjęcia innej decyzji przy weryfikacji hipotezy. Przedstawiana w dalszej części modyfikacja procedury testowej ma za zadanie usunięcie wskazanej niedogodności.

Propozycja modyfikacji oparta jest na projekcie zaproponowanym przez R.V. Hogg i współpracowników [1975] z uwzględnieniem wyników prac L. Hao i D. Houser związane z potrzebą odrzucenia testu mediany. Podobnie jak w powyżej przedstawionych testach wyznaczane są odporne mierniki asymetrii (3) i kurtozy (4). Przyjęto trzy obszary (por. rys. 2), jednak zamiast dokonywania wyboru statystyki testowej przyjmuje się postać funkcyjną statystyki z wagami. Statystyka ta może zostać zapisana następująco:

$$
T=\alpha_{1} T_{1}+\alpha_{2} T_{2}+\alpha_{3} T_{3},
$$

gdzie: $T_{1}, T_{2}$ i $T_{3}\left(T_{1}\right.$ - statystyka testu Wilcoxona, $T_{2}$ - statystyka testu dla prawoskośnego rozkładu, $T_{3}$ - statystyka testu dla rozkładów o „lekkich ogonach”) są statystykami wykorzystywanymi zgodnie ze schematem na rys. 2. Statystyki te mogą być zapisane następująco (por. [Hao i Houser 2012]) 


$$
T_{1}=\sum_{i=1}^{n_{1}} R_{i}-\frac{n_{1}\left(n_{1}+1\right)}{2},
$$

gdzie: $R_{i}$ - ranga $i$-tej obserwacji w połączonych próbach.

$$
T_{j}=\sum_{i=1}^{n_{1}} a\left(R_{i}\right) \text { dla } j=2,3,
$$

gdzie: $a\left(R_{i}\right)$ dla statystyki $T_{2}$ określone jest następująco:

$$
a\left(R_{i}\right)=\left\{\begin{array}{ccc}
R_{i}-\text { floor }[25 \%(N+1)]-1 & \text { dla } & R_{t} \leq(N+1) / 2 \\
0 & \text { dla } & R_{i}>(N+1) / 2
\end{array}\right.
$$

gdzie floor $(x)$ oznacza zaokrąglenie wartości $x$ do największej liczby całkowitej mniejszej lub równej $x$.

Dla statystyki $T_{3}$ wielkości $a\left(R_{i}\right)$ są określone następująco

$$
a\left(R_{i}\right)=\left\{\begin{array}{ccc}
R_{i}-\text { floor }[25 \%(N+1)]-0,5 & \text { dla } & R_{i} \leq 25 \%(N+1) \\
R_{i}-\text { ceiling }[75 \%(N+1)]-0,5 & \text { dla } & R_{i} \geq 75 \%(N+1) \\
0 & \text { dla } & R_{i} \in(25 \%(N+1), 75 \%(N+1))
\end{array}\right.
$$

a ceiling $(x)$ to zaokrąglenie wartości $x$ do najmniejszej liczby całkowitej większej lub równej $x$.

Kluczowy w prezentowanej modyfikacji testu HFR jest dobór wag $\alpha_{1}, \alpha_{2}$ i $\alpha_{3}$ występujących we wzorze (5). Wagi powinny być tak dobrane, aby w danym obszarze największa była waga dla statystyki wykorzystywanej w tym obszarze przez test $H F R$. Niech dane punkty $P_{1}\left(x_{1}, y_{1}\right)=P_{1}(1,3), P_{1}\left(x_{2}, y_{2}\right)=P_{2}(3,2)$ oraz $P_{1}\left(x_{3}, y_{3}\right)=P_{3}(1,1)$. Wówczas wagi niech będą określone następująco

$$
\alpha_{i}=\alpha_{i}(x, y)=\frac{w_{i}(x, y)}{W(x, y)} \text { dla } i=1,2,3,
$$

gdzie: $w_{i}(x, y)=e^{-\left[\left(x-x_{i}\right)^{2}+\left(y-y_{i}\right)^{2}\right]}$ dla $i=1,2,3$.

$$
W(x, y)=\sum_{i=1}^{3} w_{i}(x, y),
$$

gdzie: $\left(x_{i}, y_{i}\right)$ jest punktem przyjętym jako reprezentant $i$-tego obszaru. Takie określenie wag zapewnia, że w poszczególnych obszarach (rys. 2) największa waga odpowiada statystyce wykorzystywanej w teście HFR.

Ponieważ rozkład statystyki (5) w ogólnym przypadku nie jest znany, do podjęcia decyzji odnośnie do hipotezy $H_{0}$ zostanie wykorzystany test permutacyjny (por. [Good 2005]). Po pobraniu prób o liczebnościach $n_{1}$ i $n_{2}$ obliczana jest wartość statystyki i oznaczana przez $T_{0}$. Następnie połączone próby $B$-krotnie $(B \geq 1000)$ są losowo dzielone na dwie o liczebnościach $n_{1}$ i $n_{2}$. Każdorazowo obliczana jest wartość statystyki $T_{i}(i=1,2, \ldots, B)$. Ostateczna decyzja podejmowana jest na podstawie oceny ASL (achieving significance level). Ocena ASL w przy- 
padku hipotezy alternatywnej obustronnej przy poziomie istotności $\alpha=0,05$ przyjmuje postać (por. [Efron i Tibshirani 1993]):

$$
A \hat{S} L=\frac{\operatorname{card}\left\{i: T_{i}>T^{(0,975)} \vee T_{i}<T^{(0,025)}\right\}}{B},
$$

gdzie: $T^{(q)}$ jest kwantylem rzędu $q$ empirycznego rozkładu statystyki $T$, która jest kombinacją liniową statystyk $T_{1}, T_{2}$ i $T_{3}$ (por. 5).

\section{Analiza symulacyjna}

Celem przeprowadzonego badania było porównanie wyników testowania hipotezy o równości wartości oczekiwanych testem $H H$, testem $t$ oraz proponowaną modyfikacją (oznaczenie $m H F R$ ). Analizy przeprowadzono z wykorzystaniem symulacji komputerowych. Próby o liczebności $n_{1}=n_{2}=15$ były pobierane z populacji o różnych charakterystykach. W analizach uwzględniono rozkłady opisywane w [O'Gorman 2012]: $D_{1}$ - jednostajny, $D_{2}-$ normalny, $D_{3}-t$-Studenta, $D_{4}-$ dwumodalny symetryczny (mieszanka rozkładów normalnych), $D_{5}-$ skośny z małą kurtozą (uogólniony rozkład lambda), $D_{6}-$ dwumodalny skośny (mieszanka rozkładów normalnych). Charakterystyka powyższych rozkładów została przedstawiona w tabeli 1.

Tabela 1. Charakterystyka rozkładów wykorzystywanych w symulacjach

\begin{tabular}{|c|l|c|}
\hline Rozkład & \multicolumn{1}{|c|}{ Opis } & Oznaczenie i parametry \\
\hline$D_{1}$ & jednostajny & $U[-\sqrt{3} ; \sqrt{3}]$ \\
\hline$D_{2}$ & normalny standardowy & $N(0,1)$ \\
\hline$D_{3}$ & $t$-Studenta o 4 stopniach swobody & $t_{4}$ \\
\hline$D_{4}$ & mieszanka rozkładów normalnych & $\frac{1}{2} N\left(-\sqrt{\frac{9}{13}}, \frac{4}{13}\right)+\frac{1}{2} N\left(\sqrt{\frac{9}{13}}, \frac{4}{13}\right)$ \\
\hline$D_{5}$ & uogólniony rozkład lambda & $\Lambda(0 ; 1 ; 1 ; 4,2)$ \\
\hline$D_{6}$ & dwumodalny skośny & $\frac{2}{3} N\left(-\frac{1}{2}, \frac{1}{4}\right)+\frac{1}{3} N\left(\frac{3}{2}, \frac{1}{4}\right)$ \\
\hline
\end{tabular}

Źródło: opracowanie własne na podstawie: [Hao i Houser 2012].

Wykresy gęstości rozważanych rozkładów przedstawiono na rys. 3. We wszystkich przeprowadzonych symulacjach przyjęto poziom istotności $\alpha=0,05$. Przebieg procedury symulacyjnej był następujący:

1) generowano dwie próbki o liczebnościach $n_{1}=n_{2}=15$ z rozkładów $D_{1}-D_{6}$. Dla każdego rozkładu generowano 1000 par próbek. Rozważano dwa przypadki: 
- $H_{0}$ prawdziwa,

- $H_{0}$ fałszywa - druga z próbek miała zawsze wartość oczekiwaną powiększoną o $\delta=0,6 \sigma$;

2) na podstawie danych połączonych prób obliczano mierniki (3) i (4) i na tej podstawie wyznaczano współczynniki funkcji testowej (5);

3) obliczano wartość statystyki $T_{0}$. Następnie przeprowadzano losowy podział połączonego zbioru i obliczano wartość statystyki $T_{i}(i=1,2, \ldots, 1000)$;

4) podejmowano decyzję na podstawie (6).
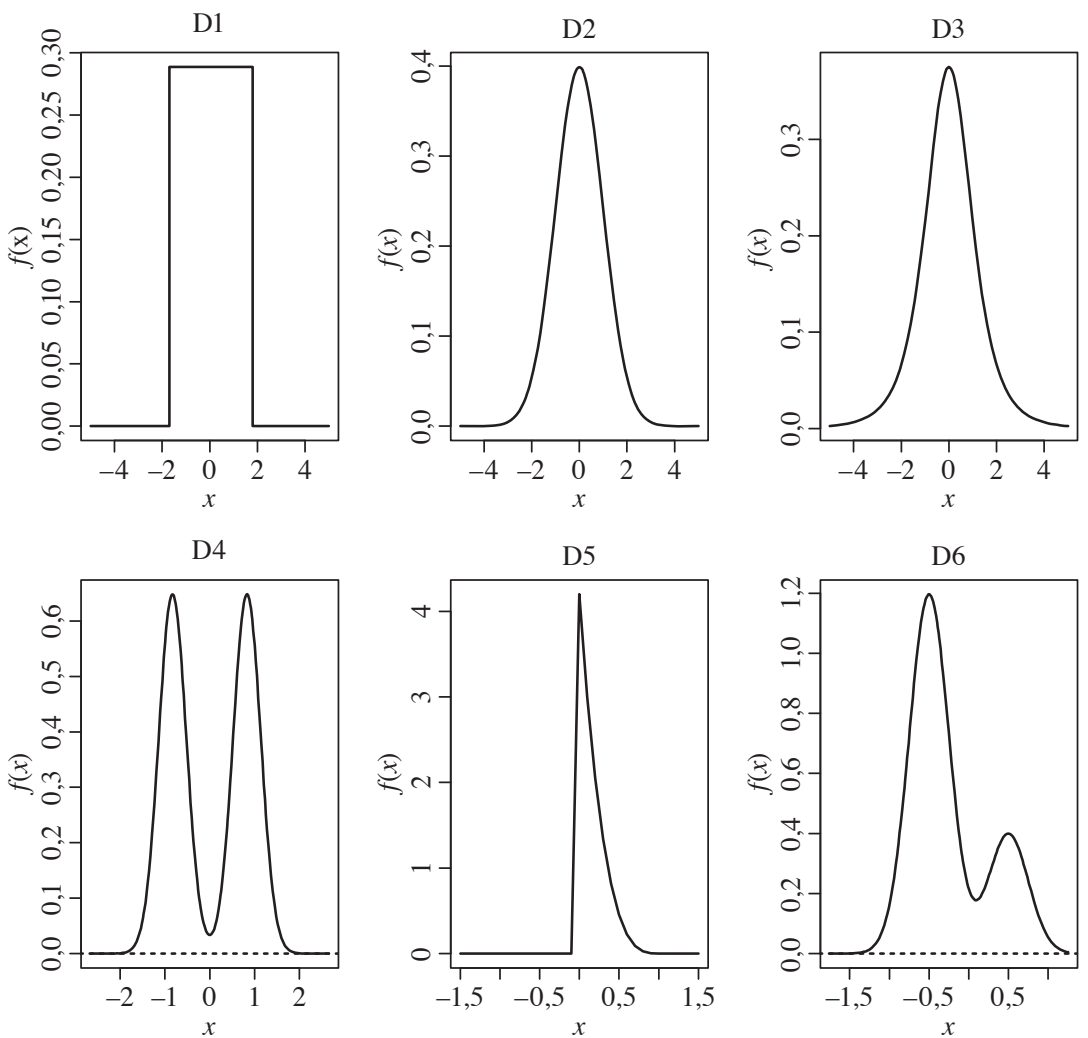

Rys. 3. Gęstości rozważanych rozkładów Źródło: opracowanie własne w programie R.

W tabeli 2 przedstawiono wyniki przeprowadzonych analiz symulacyjnych. Zaprezentowano wyniki dla przypadku, gdy $H_{0}$ jest prawdziwa (rozmiar testu) oraz gdy $H_{0}$ jest fałszywa (moc testu). Ponieważ wszystkie analizy były przepro- 
wadzone przy poziomie istotności $\alpha=0,05$, to prawdopodobieństwa odrzucenia $H_{0}$, gdy jest prawdziwa, powinny być bliskie 0,05 . Takie wartości pozwalają potwierdzić, że wnioskowanie odbywa się na przyjętym poziomie istotności.

Tabela 2. Ocena rozmiaru proponowanego testu i mocy dla wybranych rozkładów

\begin{tabular}{|c|c|c|c|c|c|c|}
\hline \multirow{2}{*}{ Rozkład } & \multicolumn{3}{|c|}{ Rozmiar testu $(\delta=0)$} & \multicolumn{3}{c|}{ Moc testu $(\delta=0,6 \sigma)$} \\
\cline { 2 - 7 } & $H H$ & $m H F R$ & $t$ & $H H$ & $m H F R$ & $t$ \\
\hline$D_{1}$ & 0,047 & 0,064 & 0,058 & 0,125 & 0,120 & 0,103 \\
\hline$D_{2}$ & 0,044 & 0,044 & 0,043 & 0,320 & 0,371 & 0,388 \\
\hline$D_{3}$ & 0,038 & 0,047 & 0,044 & 0,419 & 0,446 & 0,399 \\
\hline$D_{4}$ & 0,013 & 0,012 & 0,002 & 0,894 & 0,715 & 0,116 \\
\hline$D_{5}$ & 0,035 & 0,046 & 0,044 & 0,421 & 0,568 & 0,376 \\
\hline$D_{6}$ & 0,022 & 0,027 & 0,000 & 0,940 & 0,978 & 0,039 \\
\hline
\end{tabular}

Źródło: opracowanie własne.

W przypadku gdy $H_{0}$ jest fałszywa, przyjmowano, że wartość oczekiwana drugiej próbki jest o $0,6 \sigma$ większa od wartości oczekiwanej pierwszej próby. Wyniki symulacji zamieszczone w tabeli 2 zostały zobrazowane na rys. 4 i 5 .

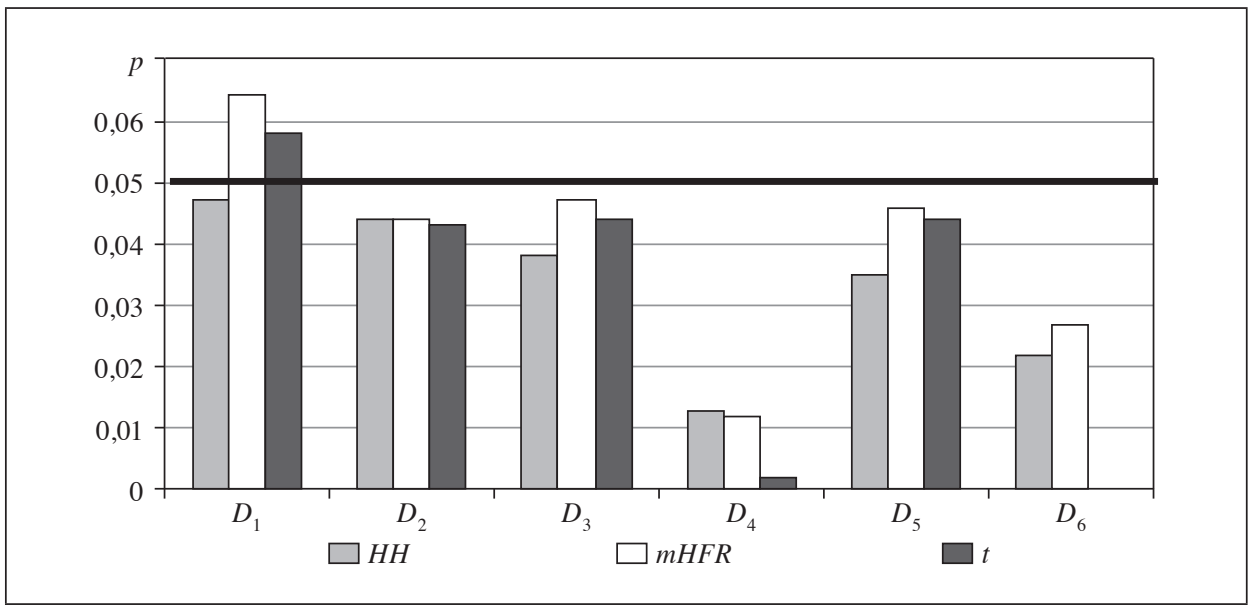

Rys. 4. Rozmiar testów

Źródło: opracowanie własne na podstawie danych z tabeli 2.

Dla rozkładów $D 4$ i $D 6$ test $t$ nie prowadzi do weryfikacji hipotezy przy poziomie istotności $\alpha=0,05$. Prawdopodobieństwa odrzucenia $H_{0}$ są znacznie mniejsze niż przyjęty poziom istotności. Dla pozostałych rozkładów wniosko- 


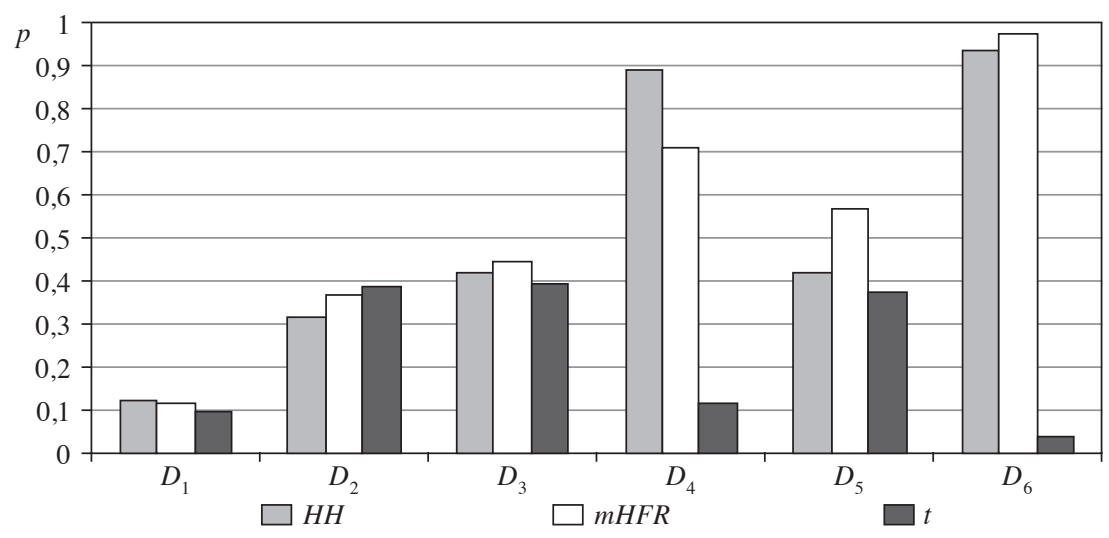

Rys. 5. Moc testów

Źródło: opracowanie własne na podstawie danych z tabeli 2.

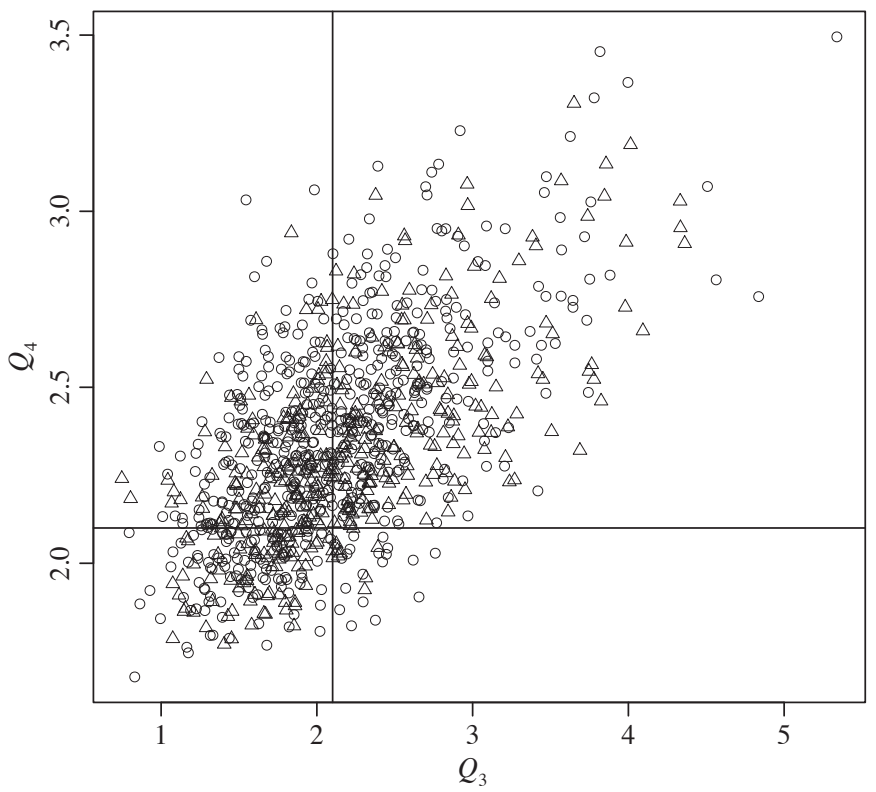

Rys. 6. Rezultaty weryfikacji hipotezy $H_{0}(\triangle$ - odrzucenie, $\bigcirc-$ brak podstaw do odrzucenia) w zależności od $Q_{3}$ i $Q_{4}$

Źródło: opracowanie własne. 
wanie jest przeprowadzane zgodnie z przyjętym poziomem istotności. Moc testów $H H$ oraz proponowanej modyfikacji we wszystkich rozważanych przypadkach $m H F R$ jest zbliżona.

Istotą przedstawionej propozycji jest usunięcie swoistej nieciągłości związanej z testami $H F R$ i $H H$ w pobliżu granic, gdy wartości $Q_{3}$ lub $Q_{4}$ są bliskie 2,0 lub 2,1 (por. rys. 1 i 2). Dla uzyskania ocen rozmiaru $(\delta=0)$ i mocy testów $(\delta=0,6 \sigma) H H$ i $m H F R$ przeprowadzono 10000 symulacji dla danych generowanych z rozkładu $D_{5}$. Pierwsze 500 wyników testu $m H F R$ przedstawiono na rys. 6 . Symbole trójkąta oznaczają odrzucenie $H_{0}$, a symbole koła brak podstaw do odrzucenia $H_{0}$.

Na rys. 7 przedstawiono wykresy konturowe rozmiaru testów $H H$ oraz mHFR (hipoteza $H_{0}$ prawdziwa) w obszarze $\mathrm{Q}_{3} \times \mathrm{Q}_{4} \in[1,8 ; 2,4] \times[1,8 ; 2,4]$, czyli w obszarze, gdzie w teście $H H$ wykorzystywane są trzy warianty statystyki testowej. Rozmiar obu testów jest na podobnym poziomie i charakteryzuje się zbliżonym zróżnicowaniem. Na rys. 8 przedstawiono oceny prawdopodobieństwa odrzucenia hipotezy $H_{0}$ w przypadku, gdy jest ona fałszywa dla rozkładu $D_{5}$. W tym przypadku dość wyraźnie widać brak regularności dla testu $H H$. Ze względu na konstrukcję statystyki testowej (5) charakterystyczna dla testu $H H$ nieregularność nie występuje w przypadku testu $m H F R$. Przy wykreśleniu funkcji rozmiaru oraz mocy testów (rys. 7 i 8) wykorzystano funkcje programu Mathematica pozwalające na rekonstrukcję przestrzennego wykresu na podstawie informacji o punktowych wartościach funkcji (ocenie rozmiaru i mocy testów).

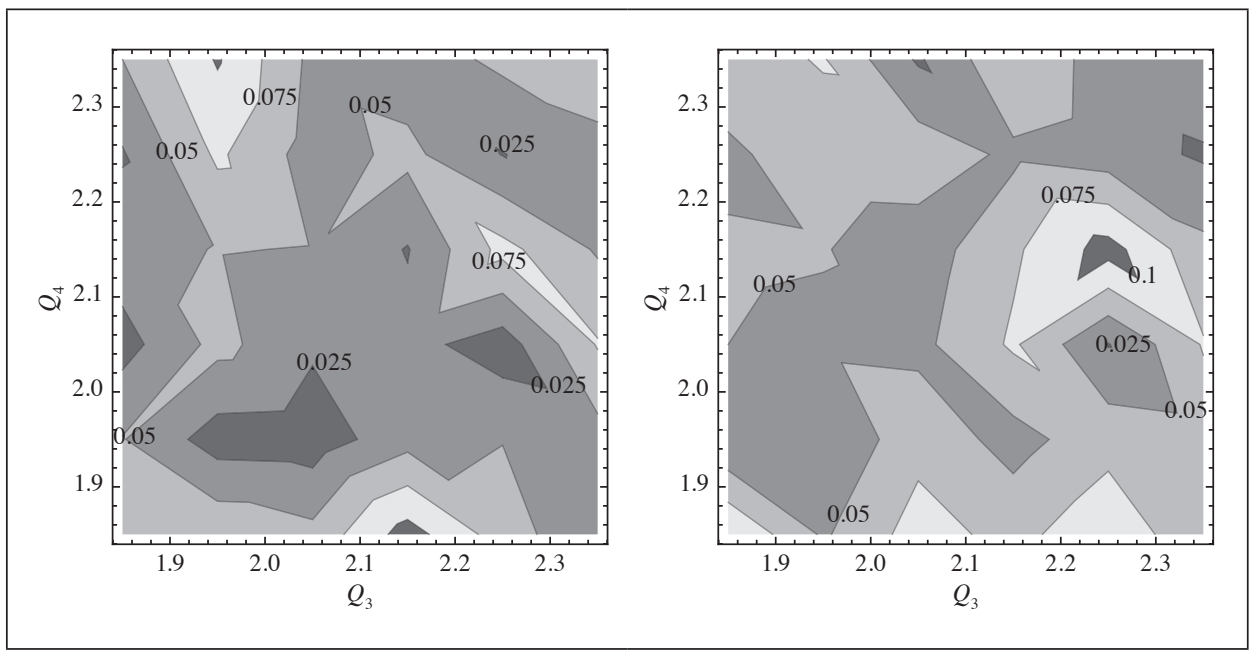

Rys. 7. Oceny rozmiaru testów ( $H_{0}$ prawdziwa) dla testu $H H$ (po lewej) oraz testu $m H F R$ (po prawej)

Źródło: opracowanie własne w programie Mathematica. 


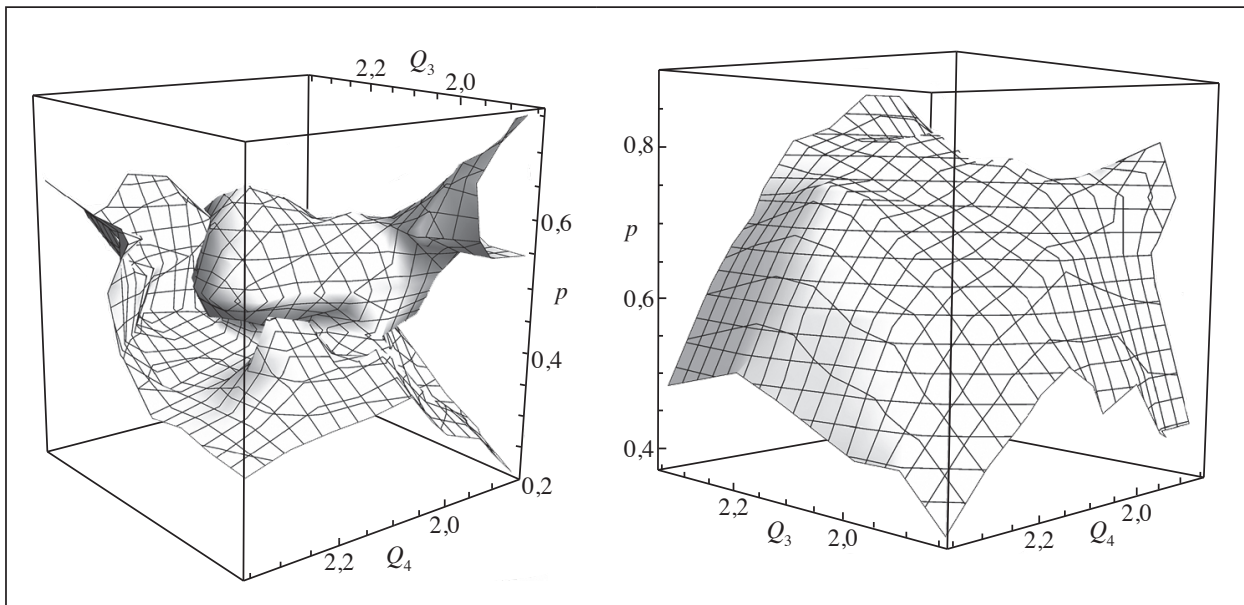

Rys. 8. Oceny mocy testów ( $H_{0}$ fałszywa) dla testu $H H$ (po lewej) oraz testu $m H F R$ (po prawej)

Źródło: opracowanie własne w programie Mathematica.

\section{Podsumowanie}

Testy adaptacyjne są rzadko wykorzystywane w badaniach ekonomicznych. $\mathrm{W}$ artykule przedstawiono propozycję modyfikacji testu adaptacyjnego dla porównania wartości oczekiwanych w dwóch populacjach. Test nie wymaga spełnienia założeń o postaci rozkładu, dlatego może być wykorzystywany np. w procedurach kontroli jakości, gdy nie jest znany rozkład zmiennej diagnostycznej. Wykorzystując symulacje komputerowe, przeprowadzono porównania własności proponowanego testu oraz testu Hogga i Housera. Proponowana modyfikacja charakteryzuje się zbliżoną mocą do mocy testu $H H$. Ze względu na konstrukcję statystyki testowej funkcja mocy testu jest bardziej regularna niż w przypadku testu $H H$, gdzie w zależności od wartości odpornych mierników asymetrii i kurtozy są wykorzystywane różne postaci statystyki testowej. Należy jednak podkreślić, że ze względu na wykorzystanie testu permutacyjnego niezbędne jest wykonanie złożonych obliczeń, więc stosowanie proponowanej modyfikacji jest nieco bardziej uciążliwe i nie zawsze będzie możliwe jej wykorzystanie w praktyce. 


\section{Literatura}

Domański C., Pruska K. [2000], Nieklasyczne metody statystyczne, PWE, Warszawa.

Efron B., Tibshirani R. [1993], An Introduction to the Bootstrap, Chapman \& Hall/ CRC, Boca Raton, Washington, DC.

Good P. [2005], Permutation, Parametric, and Bootstrap Tests of Hypotheses, Springer, New York.

Hao L., Houser D. [2012], Adaptive Procedures for Wilcoxon-Mann-Whitney Test: Seven Decades of Advances, http://comp.uark.edu/ lhao/adaptive.pdf.

Hogg R.V., Fisher D.M., Randles R.H. [1975], A Two-sample Adaptive Distribution-free Test, ,Journal of the American Statistical Associacion”, vol. 70, http://dx.doi. org $/ 10.2307 / 2285950$.

O'Gorman T.W. [2012], Adaptive Tests of Significance Using Permutations of Residuals with $R$ and $S A S$, John Wiley and Sons, New Jersey.

Sheskin D.J. [2003], Handbook of Parametric and Nonparametric Statistical Procedures, Chapman \& Hall, Boca Raton.

\section{On the Modification of the Adaptive Test for Comparing Means}

(Abstract)

The paper presents a proposal of a modification of the L. Hao and D. Houser adaptive test for comparing the locations of two distributions. The modification is based on the linear combination of three test statistics. In the Hao and Houser test, due to the values of the robust asymmetry and shape characteristics, the test statistic is chosen. A method of continuous modification of the test statistic is presented. The properties of the proposed procedure are analyzed in a Monte Carlo study. The proposal could be used in quality control monitoring processes.

Keywords: adaptive tests, permutation tests, comparing populations, Monte Carlo. 